\title{
PERAN PENULISAN KARYA ILMIAH DAN PTK BAGI PROFESIONALISME GURU SENI BUDAYA
}

\author{
Oleh: \\ Trisakti $^{1}$, Anik Juwariyah ${ }^{2}$, Setyo Yanuartuti ${ }^{3}$, Warih Handayaningrum ${ }^{4}$ \\ 1,2,3,4 Universitas Negeri Surabaya \\ 1 trisakti@unesa.ac.id \\ ²anikjuwariyah@unesa.ac.id
}

\begin{abstract}
Abstrak
Kegiatan pelatihan ini dilatarbelakangi dari kebutuhan guru dalam memenuhi kewajiban penyusunan karya ilmiah untuk kenaikan pangkat dan bukti dokumen prestasi guru seni budaya dalam penulisan karya ilmiah. Kegiatan ini bertujuan meningkatkan pemahaman dan ketrampilan guru seni budaya dalam menyusun karya ilmiah dan Penelitian Tindakan Kelas (PTK) melalui pelatihan. Pelatihan dilaksanakan dengan metode ceramah, diskusi, pemberian tugas dan bimbingan. Hasil angket kemampuan peserta dalam penyusun PTK menunjukkan 92\% sangat baik, kemampuan dalam menyusun PTK dan karya ilmiah menunjukkan prosentase nilai baik pada aspek pemahaman isi materi yang disajikan $84,6 \%$, aspek kemudahan menemukan ide dalam menulis PTK 69\%, kemampuan dalam mengembangkan tulisan PTK dengan baik 69\%. Respon terhadap aspek tentang PTK yang mendukung proses pembelajaran menunjukkan 61,5\%, sedangkan pendapat terhadap PTK yang dihasilkan dapat dilaksanakan mendapatkan prosentase $69 \%$. Rata-rata nilai peserta menyusun proposal adalah 78 . Rata-rata nilai peserta pelatihan cukup baik, mengingat ada peserta yang belum pernah mengetahui tentang PTK karena di antara guru tersebut ada yang berlatar belakang seni murni. Prosentase nilai peserta pelatihan yang mendapat nilai di atas 70 mencapai 69\%, sedangkan yang $30 \%$ mendapatkan nilai 60 ke bawah. Hal ini menunjukkan bahwa pelatihan penulisan karya ilmiah dan penyusunan PTK telah berjalan dan mendapatkan hasil yang cukup baik.
\end{abstract}

Kata Kunci: seni budaya, pelatihan, karya ilmiah, Penelitian Tindakan Kelas (PTK)

\begin{abstract}
The background for conducting the training comes from the teachers' need in fulfilling the obligation to compose scientific works for job promotion matters and teachers' achievement documentation. This activity is aimed at improving the understanding and the skills of Arts and Culture teachers in composing scientific works and Classroom Action Research through training. Furthermore, it was carried out through lecture, discussion, task giving and guidance. The results of the questionnaire showed thatthe ability of the participants in composing the Classroom Action Research is $92 \%$ very good. Also, with regard to composing the Classroom Action Researchand scientific works, it was found that based on the aspect of understanding the contents of the materials presented, the ability of the participants reaches $84,6 \%$ percentage. Besides, the easinessof generating ideas in writing Classroom Action Research achieves $69 \%$, while the ability of developing Classroom Action Research writing well obtains $69 \%$. In addition, the response onthe Classroom Action Research aspect supporting the learning process is 61,5\%. Meanwhile, opinion on the Classroom Action Research donethat can be applied gets 69\% percentage. The average score of the participants in writing proposal is 78. In general, the average score is satisfactory, considering that there were some participants who previously did not understand aboutClassroom Action Research because their specialty ispure art. Additionally, the percentage of the participants achieving score above 70 is $69 \%$, while the rest $30 \%$ got 60 and below. It indicates that the trainingonscientific works and Classroom Action Research writing has been successlly run and shown a noticable result.
\end{abstract}

Keywords: arts and culture, training, scientific works, classroom action research

\section{PENDAHULUAN}

Pendidikan adalah salah satu bentuk perwujudan kebudayaan manusia yang dinamis dan sarat perkembangan, oleh karena itu perubahan atau perkembangan pendidikan adalah hal yang memang seharusnya terjadi sejalan dengan perubahan budaya kehidupan masyarakat. Perubahan dalam arti perbaikan pendidikan pada semua tingkat perlu terus menerus dilakukan sebagai antisipasi kepentingan masa depan. 
Mutu produk pendidikan sangat erat kaitannya dengan proses pelaksanaan pembelajaran yang dipengaruhi oleh banyak faktor, antara lain: kurikulum, tenaga kependidikan, proses pembelajaran, saranaprasarana, alat-bahan, manajemen sekolah, lingkungan (iklim) kerja dan kerjasama industri. Kompetensi guru menjadi tuntutan peningkatan kualitas pendidikan sehingga kompetensi diartikan sebagai kebulatan pengetahuan, ketrampilan, sikap yang ditampilkan dalam bentuk perilaku cerdas dan penuh tanggung jawab dalam melaksanakan profesinya (Mulyasa, 2018; Fahdini, 2014). Guru menjadi kunci utama penentu keberhasilan pendidikan yang di dalamnya termasuk merencanakan pembelajaran, melaksanakan proses pembelajaran, melakukan strategi pembelajaran yang tepat yang didukung dengan pemanfaatan fasilitas belajar serta melakukan evaluasi yang jelas sesuai substransi yang diukur (Sulisyowati, 2018: 10).

Dalam rangka peningkatan kualitas pendidikan, khususnya pada guru-guru Seni Budaya di Propinsi Jawa Timur, berbagai program peningkatan kualitas guru telah dilaksanakan melalui pelatihan berkaitan dengan proses belajar mengajar, uji kompetensi guru, pelatihan di bidang evaluasi pembelajaran dan penelitian. Salah satu persyaratan guru dalam kenaikan pangkat adalah telah melaksanakan pengembangan keprofesionalannya melalui penulisan karya ilmiah yang dapat juga berupa penelitian tindakan kelas. Permeneg PAN dan RB Nomor 16 tahun 2009 tentang Jabatan Fungsional dan angka kredit dijelaskan bahwa Pengembangan keprofisionalan Berkelanjutan (PKB) adalah pengembangan kompetensi Guru yang dilaksanakan sesuai dengan kebutuhan, bertahap, berkelanjutan untuk meningkatkan profesionalitasan. Kegiatan PKB dalam permeneg tersebut terdiri dari tiga komponen yaitu pengembangan diri, karya ilmiah dan karya inovatif. Pada karya ilmiah, guru dapat membuat publikasi ilmiah dari hasil penelitian atau gagasan ilmu dalam bidang keilmuannya. Realisasi PKB tersebut di lapangan menunjukkan kurangnya guru dalam menulis karya ilmiah baik dalam bentuk penulisan karya hasil penuangan gagasannya ataupun dalam kegiatan penelitian. Mengkaji hal tersebut, kebutuhan guru di lapangan bukan hanya mendapatkan pengetahuan dan ketrampilan yang berhubungan dengan mata pelajaran yang diampunya, tetapi juga memerlukan pengetahuan dan ketrampilan dalam penulisan karya ilmiah. Hal tersebut sejalan dengan pendapat Kasiyan (2019: 48) yang mengatakan bahwa guru memiliki posisi yang strategis dan guru adalah ujung tombak sekaligus garda terdepan dalam keberhasilan pendidikan sehingga upaya peningkatan kompetensi perlu didukung.

Bentuk karya ilmiah yang berhubungan langsung dengan upaya peningkatan kualitas pembelajaran yang diampu oleh guru adalah dengan penelitian tindakan kelas. Penelitian Tindakan Kelas (PTK) dipandang sebagai bentuk penelitian peningkatan kualitas pembelajaran yang paling tepat karena selain sebagai peneliti guru juga bertindak sebagai pelaksana proses belajar mengajar, sehingga tahu betul permasalahan yang dihadapi dan kondisi yang ingin dicapai. PTK menjadi salah satu aspek pengembangan guru yang harus disadari, dipahami, dilaksanakan serta ditindaklanjuti oleh guru agar kualitas pembelajaran meningkat dan prestasi belajar peserta didik meningkat (Supriyanto, 2017). PTK bagi guru dilakukan oleh guru melalui tiga kegiatan yaitu membuat proposal yang menjadi input awal dari permasalahan yang terjadi di dalam kelas, menyusun laporan sebagai input untuk publikasi dan publikasi yang dapat dilakukan melalui penyusunan artikel untuk jurnal ilmiah maupun artikel untuk prosiding seminar.Undang-undang Republik Indonesia Nomor 20 tahun 2003 tentang Sistem Pendidikan Nasional menyebutkan bahwa jabatan guru sebagai pendidik adalah jabatan profesional yang menuntut guru untuk terus menerus berkembang dalam ilmu pengetahuan dan tehnologi sesuai perkembangan jaman. Hal tersebut tentunya memerlukan realisasi nyata dalam peningkatan keprofesionalitasannya. Hal ini dipertegas kembali dengan Undang Undang Republik Indonesia Nomor 14 Tahun 2005 tentang Guru dan Dosen yang menyebut profesi guru sebagai profesi yang sejajar dengan dosen di perguruan tinggi (Jaedun, 2011). Observasi awal kegiatan diketahui bahwa antusiasme guru dalam penulisan karya ilmiah masih kurang karena keterbatasan kemampuan dan pengalaman dalam bidang penelitian. Disamping itu karena keterbatasan pengetahuan dan pengalaman penelitian, hasil-hasil pelaksanaan penelitian tindakan kelas yang terlaksana masih kurang mencerminkan sebagai penelitian tindakan kelas. 
Kebanyakan hasil penelitian tindakannya masih rancu dengan penelitian dengan analisis statistik.

Dari uraian tersebut di atas, maka upaya peningkatan kompetensi guru dalam bidang penelitian perlu ditingkatkan. Untuk mendukung tercapainya profisionalitas guru memerlukan pembinaan dan pengembangan profesi yang dilakukan secara utuh serta berkelanjutan (Suyanto dan Jihad, 2013; Noorjannah, 2014). Upaya peningkatan pengetahuan dan ketrampilan guru secara utuh dan berkelanjutan dapat dilakukan melalui pelatihan. Melalui pelatihan, dapat meningkatkan kemampuan menulis karya ilmiah guru (Ardinata, 2016). Sebagai solusi dari permasalahan keterbatasan kemampuan dan pengalaman guru khususnya guru Seni Budaya dalam penulisan karya ilmiah, maka kegiatan pelatihan penulisan karya ilmiah dan PTK perlu dilakukan. Pelatihan yang dilakukan oleh tim dosen dari Universitas Negeri Surabaya (Unesa) merupakan bentuk Tri Dharma Perguruan tinggi yang menjadi solusi yang sangat tepat. Dengan adanya pelatihan penulisan karya ilmiah dan penelitian tindakan kelas akan diperoleh ketrampilan guru dalam penulisan karya ilmiah meliputi pengetahuan menyusun PTK dan ketrampilan dalam menulis proposal PTK.

Kegiatan pelatihan penulisan karya ilmiah dan PTK yang bertujuan meningkatkan pengetahuan dan ketrampilan guru dalam menyusul proposal PTK ini dilakukan pada guru yang tergabung dalam MGMP di kabupaten Banyuwangi.

\section{METODE}

Kegiatan pelatihan karya ilmiah dan PTK bagi profesionalisme guru seni budaya dilaksanakan bagi guru SMP yang tergabung dalam MGMP Pendidikan Seni Budaya di Kabupaten Banyuwangi. Kegiatan pelatihan dilakukan pada tanggal 5-7 Oktober 2016 yang diawali dengan kegiatan prsiapan penyusunan materi dan pembagian tugas tim untuk menyampaikan materi pelatihan. Kegiatan pelatihan bertempat di Aula SMK N 1 Rogojampi Banyuwang, dan SMP N 1 Puri Banyuwangi.

Pelatihan penulisan karya ilmiah dan PTK bagi guru Seni Budaya di kabupaten Banyuwangi dilaksanakan melalui dua metode, yaitu:

1. Metode pembelajaran langsung untuk menjelaskan materi pelatihan yang meliputi: Jenis-jenis penelitian pendidikan; Pengertian dan karakteristik PTK; Penyusunan proposal PTK; Pelaksanaan PTK; dan Penyusunan Laporan PTK.

2. Metode pembelajaran terbimbing atau pendampingan untuk menyelesaikan tugas penyusunan proposal yaitu melalui bimbingan langsung antara guru dengan pelatih.

Teknik pengumpulan data dalam pelatihan ini menggunakan angket untuk mengetahui tingkat pencapaian materi yang telah disampaikan pelatih. Disamping itu untuk mengetahui keberhasilan ketrampilan guru dalam menyusun proposal dilakukan dengan teknik pengumpulan tugas menyusun proposal PTK. Teknik analisis data menurut Sugiyono (2010: 335) adalah proses mencari, menyusun secara sistematis data dari teknik pengumpulan data dengan cara mengorganisasikan data dalam kategori, menjabarkan data dalam unit-unit, melakukan sistesis dan menyimpulkan.

\section{HASIL DAN PEMBAHASAN}

Pelatihan penulisan karya ilmiah dan PTK ini diikuti oleh 13 orang guru yang tergabung dalam MGMP Seni Budaya Kabupaten Banyuwangi. Peserta pelatihan pada umumnya memiliki pendidikan terakhir S1, hanya 1 (satu) otrang yang memiliki pendidikan terakhir S 2. Berdasarkan biodata ditinjau dari pengalaman melakukan penelitian pada umumnya guru-guru peserta PKM belum pernah melakukan penelitian kecuali pada saat menyelesaikan pendidikan S1 (Skripsi).

Pelatihan dilakukan dalam dua tahap yaitu penyampaian materi umum dan pendampingan. Pada penyampaian materi pelatihan secara berurutan disampaikan materi tentang penulisan karya ilmiah dan PTK. Pemateri pertama adalah Dr. Anik Juwariyah, M.Si yang menyampaikan mengenai penyusunan proposal, pelaksanaan, dan laporan PTK pendidikan seni budaya. Materi ini disampaikan dengan diawali pengantar bahwa betapa pentingnya pelaksanaan PTK bagi guru. PTK dilakukan dengan tujuan untuk memperbaiki proses dan hasil pembelajaran. Penelitian tindakan kelas merupakan penelitian yang mudah dilakukan oleh guru, karena guru merupakan satusatunya orang yang mengetahui bagaimana kelemahan-kelemahan dan kelebihan proses pembelajaran yang dilakukannya di kelas, 
serta guru merupakan orang yang mengetahui karakteristik anak didik yang dihadapinya. Pelaksanaan PTK akan dapat berjalan dengan baik jika disiapkan perencanaan atau disebut dengan proposal PTK. Pendidikan Seni Budaya merupakan mata pelajaran yang unik, yang memiliki karakteristik tersendiri dalam proses dan hasil pembelajarannya. Keunikan dan karakteristik pendidikan ini menyebabkan permasalahanpermasalahan yang muncul dalam pembelajaran tentu berbeda dan kemungkinan penanganan atau perbaikan yang harus dilakukan berbeda dengan mata pelajaran lain. Materi ini disampaikan untuk dapat memotivasi peserta pelatihan ini. Berangkat dari latar belakang permasalahan dalam kelas mata peajaran pendidikan seni budaya, seorang guru sekaligus peneliti dapat melakukan refleksi dan merumuskan permasalahan proposal PTK. Penyusunan proposal penelitian PTK wajib dilakukan agar usaha perbaikan dan peningkatan proses atau hasil pembelajaran dapat terlaksana dengan baik.

Materi penyusunan proposal, pelaksanaan dan laporan PTK dilanjutkan dengan pendampingan penyusunan proposal. Target dari pelaksanaan PTK ini adalah terselesaikannya rancangan penelitian PTK atau proposal PTK. Dengan harapan rancangan PTK yang telah dihasilkan dapat dilaksanakan dan diterapkan di kelas oleh guru masing-masing. Pendampingan penyusunan proposal PTK dipandu oleh Dr. Setyo Yanuartuti, M.Si, dan dilanjutkan dengan pendampingan oleh Dr. Trisakti, M.Si dan Dr. Warih Handayaningrum, M.Pd. Proposal PTK yang telah diselesaikan oleh peserta pelatihan kemudian dipresentasikan di depan kelas untuk mendapatkan tanggapan dan masukan oleh instruktur dan peserta lain. Di antara peserta pelatihan PKM pendidikan Seni Budaya hanya 1 (satu) orang yang belum berhasil menyelesaikan proposalnya.

Hasil sebuah kegiatan dapat dilihat dari kelancaram proses kegiatan, tanggapan peserta terhadap rangkaian pelaksanaan kegiatan dan hasil dari kegiatan. Dalam konteks pengabdian kepada masyarakat ini, proses kegiatan dapat dilihat dari kelancaran kegiatan. Kegiatan pengabdian kepada masyarakat ini telah berjalan dengan baik tanpa adanya hambatan yang berarti dari proses keberangkatan, kegiatan inti yakni pelatihan sampai pada penutupan.

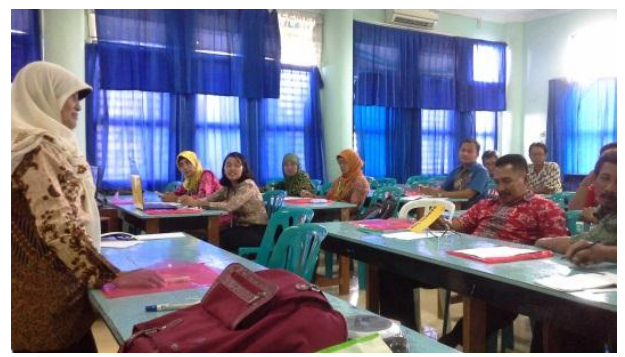

Gambar 1. Penyampaian Materi PTK oleh Pelatih

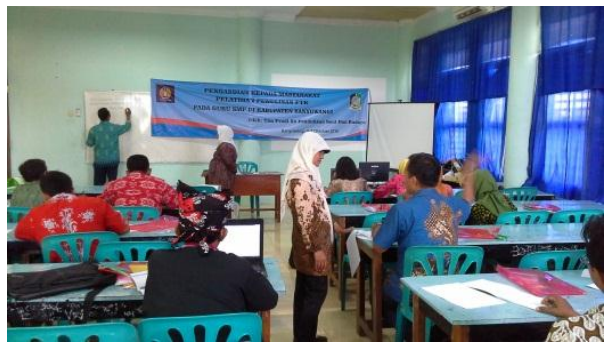

Gambar 2. Pelatih Mendampingi Peserta Menyusun PTK

Pelaksanaan kegiatan pada guru-guru di Kabupaten Banyuwangi pada umumnya berjalan dengan baik. Terlihat bahwa guruguru yang hadir dari awal pembukaan di hari pertama, selama proses pelatihan hingga pelatihan penyusunan proposal dan penulisan karya ilmiah selesai, jumahnya tetap sama yakni 13 orang. Berkaitan dengan kenyamanan, dan kepuasan para peserta pelatihan, para peserta pada umumnya merasa puas dan merespon baik bahkan sangat baik. Hal ini dapat dilihat dari hasil kuisener yang telah disebarkan oleh tim PKM kepada peserta. Berikut hasil responden dari peserta berkaitan dengan pelaksanaan PKM. 
Tabel 1. Hasil Tanggapan Responden Berkaitan dengan Pelaksanaan Pelatihan

\begin{tabular}{|c|c|c|c|c|c|c|c|c|c|c|c|c|c|c|}
\hline \multirow[t]{2}{*}{ No } & \multirow[t]{2}{*}{ Aspek yang dinilai } & \multicolumn{12}{|c|}{ Responden } & \multirow[t]{2}{*}{ Jumlah } \\
\hline & & 1 & 2 & 3 & 4 & 5 & 6 & 7 & 8 & 9 & 10 & 11 & 1213 & \\
\hline 1 & $\begin{array}{l}\text { Penyajian dasar pada } \\
\text { saat pleno }\end{array}$ & 3 & 4 & 4 & 3 & 4 & 3 & 3 & 4 & 3 & 3 & 3 & 4 & $\begin{array}{l}4=5 \\
3=8\end{array}$ \\
\hline 2 & $\begin{array}{l}\text { Isi Materi yang } \\
\text { diperlukan untuk } \\
\text { menunjang } \\
\text { kemampuan menulis }\end{array}$ & 3 & 4 & 4 & 4 & 3 & 3 & 3 & 4 & 3 & 3 & 3 & 3 & $\begin{array}{l}4=4 \\
3=9\end{array}$ \\
\hline 3 & $\begin{array}{l}\text { Kesempatan untuk } \\
\text { Berdiskusi }\end{array}$ & 3 & 3 & 4 & 4 & 3 & 3 & 4 & 4 & 4 & 4 & 4 & 4 & $\begin{array}{l}4=8 \\
3=5\end{array}$ \\
\hline 4 & $\begin{array}{l}\text { Pendampingan yang } \\
\text { diberikan dalam } \\
\text { penulisan }\end{array}$ & 3 & 4 & 4 & 4 & 4 & 4 & 4 & 4 & 4 & 4 & 4 & 4 & $\begin{array}{l}4=12 \\
3=1\end{array}$ \\
\hline 5 & $\begin{array}{l}\text { Ketersediaan bahan } \\
\text { untuk penulisan }\end{array}$ & 3 & 4 & 2 & 4 & 3 & 2 & 3 & 2 & 2 & 2 & 3 & 34 & $\begin{array}{l}4=3 \\
3=5 \\
2=5\end{array}$ \\
\hline
\end{tabular}

Tabel 2. Hasil Tanggapan Peserta Pelatihan Terhadap Kemampuannya dalam Menulis PTK/Karya Ilmiah

\begin{tabular}{|c|c|c|c|c|c|c|c|c|c|c|c|c|c|c|}
\hline \multirow[t]{2}{*}{ No } & \multirow[t]{2}{*}{ Aspek yang dinilai } & \multicolumn{12}{|c|}{ Responden } & \multirow[t]{2}{*}{ Jumlah } \\
\hline & & 1 & 2 & 3 & 4 & 5 & 6 & 7 & 8 & 9 & 10 & 11 & 1213 & \\
\hline 1 & $\begin{array}{l}\text { Pemahaman isi materi } \\
\text { yang disajikan }\end{array}$ & 3 & 3 & 4 & 3 & 3 & 3 & 4 & 3 & 3 & 3 & 3 & 3 & $\begin{array}{l}4=2 \\
3=11\end{array}$ \\
\hline 2 & $\begin{array}{l}\text { Kemudahan } \\
\text { menemukan ide dalam } \\
\text { menulis PTK }\end{array}$ & 3 & 2 & 3 & 3 & 3 & 3 & 4 & 3 & 3 & 3 & 4 & 3 & $\begin{array}{l}4=2 \\
3=9 \\
2=2\end{array}$ \\
\hline 3 & $\begin{array}{l}\text { Dapat } \\
\text { mengembangkan } \\
\text { tulisan PTK dengan } \\
\text { baik }\end{array}$ & 2 & 3 & 3 & 3 & 3 & 3 & 3 & 2 & 3 & 3 & 3 & 2 & $\begin{array}{l}4=0 \\
3=9 \\
2=4\end{array}$ \\
\hline 4 & $\begin{array}{l}\text { PTK yang dihasilkan } \\
\text { akan mendukung } \\
\text { proses pembelajaran } \\
\text { yang saya lakukan }\end{array}$ & 2 & 3 & 3 & 4 & 4 & 3 & 4 & 2 & 3 & 3 & 3 & 3 & $\begin{array}{l}4=3 \\
3=8 \\
2=2\end{array}$ \\
\hline 5 & $\begin{array}{l}\text { PTK dapat } \\
\text { dilaksanakan dalam } \\
\text { kelas }\end{array}$ & 2 & 4 & 3 & 4 & 3 & 3 & 3 & 2 & 3 & 3 & 3 & 33 & $\begin{array}{l}4=2 \\
3=9 \\
2=2\end{array}$ \\
\hline
\end{tabular}

Keberhasilan kegiatan ini juga dapat dilihat dari indikator kemampuan peserta pelatihan setelah mengikuti proses pelatihan dan hasil pekerjaan yang dihasilkannya. Berdasarkan atas pendapat peserta mengenai kemampuan dalam menulis PTK/karya ilmiah pada umumnya berpendapat bahwa kemampuannya sudah baik, meskipun beberapa peserta juga ada yang masih 
merasa kurang atau sangat baik pada aspekaspek tertentu.

Pendapat tentang kemampuan menulis PTK dapat dikorelasikan dengan pekerjaan peserta yang telah dihasilkan selama mengikuti pelatihan. Hasil pekerjaan guruguru SMP di Kabupaten Banyuwangi dalam menyusun proposal PTK cukup beragam. Nilai peserta yang telah mencapai nilai di atas 80 ada 4 orang, yang di atas 70 mencapai 5 orang, yang nilainya 60 ada 3 orang dan yang 50 ada 1 orang. Sementara itu ada seorang peserta yang nilainya 50 . Kekurangan skor yang diperoleh seorang peserta tersebut disebabkan oleh karena tidak menyelesaikan pekerjaan. Nilai tertinggi hasil pekerjaan peserta dalam penyusun proposal PTK adalah 88 sedangkan yang terrendah 50 .

Rata-rata nilai peserta pelatihan dalam menyusun proposal penilaian adalah 78 . Rata-rata nilai peserta pelatihan cukup baik, mengingat bahwa peserta sebelum melakukan pelatihan ada yang belum selesai dan juga belum pernah mengetahui tentang penelitian tindakan kelas, karena di antara guru tersebut ada yang berlatar belakang seni murni.

Berdasarkan pelaksanaan dan hasil kegiatan pelatihan menunjukkan bahwa kegiatan berjalan lancar dan memperoleh hasil yang baik. Permasalahan yang sebelumnya muncul dalam kegiatan ini adalah kurangnya kemampuan, pengetahuan serta kekurang-percayaan guru-guru peserta pelatihan telah terpecahkan selama pelaksaan dan terselesaikannya dalam pelatihan ini. Kekurangan dalam hal pengetahuan dan kemampuan menyusun penelitian tindakan kelas dan juga penulisan karya ilmiah dapat didiskusikan pada saat diskusi antara instruktur dengan peserta. Pada saat diskusi para peserta menyampaikan beberapa hal yang pada intinya adalah adanya anggapan bahwa menulis itu susah, sehingga sebelum peserta melakukan penulisan pada umumnya dihantui oleh rasa tidak bisa karena menulis itu sulit. Ketika disampaikan oleh para instruktur dan juga pembimbingan penyusunan proposal para peserta baru merasakan ternyata menulis itu harus dilakukan dengan melakukan pemetaan dulu akan hal-hak yang akan ditulis, kemudian membuat alur berpikir dan bernalar berkaitan dengan munculnya sebuah fenomena. Kemunculan fenomena atau permasalahan dalam PTK harus benarbenar disadari oleh peneliti PTK, dengan melakukan refleksi sehingga benar-benat menemukan permasalahan dalam pembelajaran. Dengan demikian akan mudah mencari alternatif tindakan yang harus dilakukan.

Rata-rata nilai peserta pelatihan dalam menyusun proposal penilaian adalah 78 . Rata-rata nilai peserta pelatihan cukup baik, mengingat bahwa peserta sebelum melakukan pelatihan ada yang belum selesai dan juga belum pernah mengetahui tentang penelitian tindakan kelas, karena di antara guru tersebut ada yang berlatar belakang seni murni. Prosentase nilai peserta pelatihan yang mendapat nilai di atas 70 mencapai $69 \%$, sedangkan yang $30 \%$ mendapatkan nilai 60 ke bawah. Hal ini menunjukkan bahwa pelatihan tentang penyusuna PTK dan penulisan karya ilmiah telah berjalan dan mendapatkan hasil yang cukup baik.

\section{SIMPULAN DAN SARAN}

Kebiasaan rutinitas pembelajaran yang telah dilakukan guru-guru pendidikan seni budaya menyebabkan munculnya asumsi bahwa yang terpenting dilakukan oleh guru hanya melakukan pembelajaran. Sementara itu pelaksanaan penelitian tindakan kelas hanya merupakan kegiatan yang menambahnambahi beban guru karena sulit dikerjakan sehingga dianggap hanya untuk melengkapi persyaratan kenaikan pangkat saja.

Kekurangan kemampuan dalam menyusun PTK dan penulisan kerya ilmiah bagi guru karena pada umumnya belum melakukan praktek tahap-demi tahap. Kekurang-mampuan guru-guru dalam penyusunan PTK dapat teratasi dengan praktek langsung melalui workshop yang cenderung kepada proses pendampingan.

Kepercayaan diri peserta dalam menyusun PTK dapat diatasi dengan cara memberikan motivasi dan melalui presentasi terhadap hasil rancangannya. Hasil kerja peserta pelatihan selama proses pelatihan penyusunan proposal PTK mendapatkan hasil yang baik sehingga dapat menambah kepercayaan diri para peserta pelatihan. Dengan berhasilnya penyusunan proposal PTK ini peserta memiliki harapan ke depan untuk mengucijobakannya di kelas masingmasing

\section{Saran}

Pengembangan keprofesionalan guru perlu terus ditingkatkan agar guru dapat meningkat secara profesional dalam pengetahuan, 
ketrampilan maupun sikap. Bentuk kegiatan untuk menunjang pengembangan keprofesionalan guru diantaranya guru mengikuti kegiatan seminar, workshop, pelatihan ataupun melakukan penelitian dan penulisan karya ilmiah. Untuk itu kegiatan yang dapat membantu guru mewujudkan keprofisionalan tersebut sebaiknya dilakukan secara terencana dan terprogram dengan baik agar tugas sebagai guru di sekolah dapat terlaksana dengan baik. Kerjasama kegiatan antara guru dan pihak perguruan tinggi akan dapat menghasilkan pengetahuan dan ketrampilan guru untuk menunjang keprofesionalan guru.

\section{DAFTAR PUSTAKA}

Fahdini, R.. Mulyadi, E., Suhandani, D., \& Julia, J. 2014. Identifikasi Kompetensi Guru Sebagai Cerminan Profesionalisme Tenaga Pendidik Di Kabupaten Sumedang. Mimbar Sekolah Dasar, 1 (1),33- 42. Doi: Http://Dx.Doi.Org/10.17509/Mimbar Sd.V1i1.1362

Jaedun, Ahmad. 2011. "Pengembangan Profesionalisme Guru Melalui Penulisan Karya Tulis IImiah" makalah disampaikan pada Kegiatan Seminar Karya Tulis IImiah dan Penelitian Tindakan Kelas di SMK Negeri 1 Sedayu, Bantul, Tanggal 23 Juli 2011.

Kasiyan, B Muria, Zulfi, Aran. 2019. Pelatihan Penulisan Karya IImiah Untuk Peningkatan Profesionalisme Guru. Jurnal Pengabdian Dan Pemberdayaan Masyarakat Issn: 2549-8347 (Online), Isnn: 2579-9126 (Print) Volume 3 No. 1 Maret 2019

Noorjannah, L. 2014. Pengembangan Profesionalisme Guru Melalui Penulisan Karya Tulis IImiah Bagi Guru Profesional Di SMA Negeri 1 Kauman Kabupaten Tulungagung. Jurnal Humanity, 10, (1), 98-114.

Raya Sulistyowati, Siti Sri Wulandari, Bambang Suratman, Harti. 2018. Peningkatan Kompetensi Guru Bidang Keahlian Bisnis Manajemen Melalui Penelitian Tindakan Kelas. Jurnal Abdi Vol.4 No.1 Juni 2018, Hal. 6 - 11 P-Issn: 2460-5514 E-Issn: 2502-6518 6
Sugiyono. 2010. Metode Penelitian Pendidikan Pendekatan Kuantitatif, kualitatif, dan R\&D. Bandung: Alfabeta

Supriyanto, Achmad. Peningkatan Kemampuan Guru Dalam Penulisan Karya IImiah Melalui Pelatihan Penelitian Tindakan Kelas dalam jurnal Abdimas Pedagogi, Volume 1 Nomor 1, Oktober 2107: 1-7.

Suyanto \& Jihad, A. 2015. Menjadi Guru Profesional: Strategi Meningkatkan Kualifikasi Dan Kualitas Guru Di Era Global. Surabaya: Erlangga

Undang-undang Nomor 20 Tahun 2003 tentang Sistem Pendidikan Nasional. Bandung: Citra Umbara.

Undang-undang Nomor 14 Tahun 2005 tentang Guru dan Dosen. Jakarta: Fokus Media 